\title{
A STUDENT'S SCIENTIFIC MIND: A CONFIRMATORY FACTOR ANALYSIS
}

\author{
${ }^{1}$ Oranit Chokchai \& ${ }^{2}$ Phadungchai Pupat \\ Faculty of Industrial Education and Technology \\ King Mongkut's Institute of Technology Ladkrabang \\ Bangkok, Thailand
}

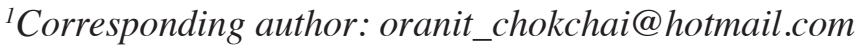

\begin{abstract}
Purpose - The research aimed to examine the construct validity of a scientific-mind measurement model for secondary school students in Bangkok and the factor loading values of scientific-mind indicators.

Methodology - Stratified random sampling was used to select a sample of 500 Grade 8 students studying in a Bangkok school district during the 2016 academic year. Testing of scientificmind measurement was used as the research instrument and construct validity testing of the scientific-mind measurement model utilized second-order confirmatory factor analysis (CFA) was carried out with SPSS AMOS software Version 23.
\end{abstract}

Findings - The testing of the scientific-mind measurement model for secondary school students in Bangkok was consistent with the empirical data. The scientific-mind factors consisted of two indicators, including scientific attitudes and attitudes towards science. Scientific attitudes were comprised of nine indicators. The indicator with the highest factor loading value was creatively working with other people. Attitudes towards science contained four indicators. The indicator with the highest factor loading value was science value awareness.

Significance - The results revealed that teachers and educational administrators have the potential to use the study's scientificmind factors in their approaches to course development, as well 
as in designing a manual for learning management. The study's model can also help in measurement and evaluation of secondary school students' progress in developing a better scientific mind.

Keywords: Confirmatory factor analysis (CFA), scientific attitudes, scientific mind, secondary students, science attitudes.

\section{INTRODUCTION}

It seems that citizens of most modern industrial countries live in a scientific and technological 'culture,' in which daily living is significantly impacted upon by science (Miller, 1996). Some authors also argue that scientific literacy is essential for participation in democracy, political activities (Süerdem \& Çağlıyor, 2016) and as a key to good citizenship (Lee \& Roth, 2003). However, what is a scientific mind?

According to Feist (2006), scientific thinking is a hallmark intellectual achievement of the human species, with the flexibility of humans to learn virtually whatever our environment throws at us, the signature trait of the human species. Furthermore, formal science-science as we know it -is but one specific expression of scientific thinking.

A scientific mind, therefore, is a mind which questions everything around it and within it. A scientific mind also seeks answers, reasons, and explanations. Furthermore, a scientific mind is an essential tool for learning, which includes attitudes and skills that come from habits of the mind. It must be expressed by knowledge, learning, thinking, and practice (American Association for the Advancement of Science, 1993; Brearton, 1996).

Furthermore, Chin (2005) discussed scientific literacy domains, which were indicated to include science content, the interaction between science, technology, the nature of science, society, and attitudes toward science. Furthermore, mathematics and science learning is crucial during the early childhood years (Clements, 2002; Connor, Morrison, \& Petrella, 2004; Hamre \& Pianta, 2005), which also affects long-term associations with school readiness and continued academic achievement (Arnold, Fisher, Doctoroff, \& Dobbs, 2002). 
Feist (2006) has also expressed his surprise at the lack of research into topics concerning the psychology of science and stated that it was not until the late 1970s that investigations began. This acknowledgement in the lack of research is also consistent with Mahoney (1979), which stated that regarding behavior patterns, affect, and even some intellectual matters, researchers know more about alcoholics, Christians, and criminals than they know about a scientist's psychology. Furthermore, researchers, educators, and employers are increasingly concerned about youth's declining interest in pursuing scientific careers and critical thinking skills (Reeve, 2016; Thailand Science Technology and Innovation Profile, 2014). Also, these concerns have reinforced the notion of scientific ignorance in the general public (Osborne, Simon, \& Collins, 2003; van Aalderen-Smeets, Walma van der Molen, \& Asma, 2012).

In Thailand where educational debate rages, educational funding takes $20 \%$ of the budget which represents $6 \%$ of the GDP. Furthermore, $80 \%$ of the educational budget gets allocated to support administrative costs, while only 5\% spent in 2013 went to boosting the quality of education (Concern over 'inefficient' education spending, 2015). Results from this process are evident as test scores continue to decline, with the 2015 Programme for International Student Assessment (PISA) results recording Thai students as being among the lowest in the world (PISA, 2015; Rujivanarom, 2016; Sothayapetch, Lavonen, \& Juuti, 2013; Yuenyong, 2013).

Also, the Thailand Research Fund (TRF) in 2016 revealed test results from 2,901 Grade 6 students, 2,305 Grade 10 students and 1,029 vocational students from 10 provinces tested for logical thinking and analytical skills. From this diverse group of 6,235 students, only $2.09 \%$ passed the exam. Furthermore, the average score was only $36.5 \%$ (Rujivanarom, 2016). Thus, educators in Thailand have called for significant reform and blamed students' low scores in the PISA on the system's failure to encourage logical thinking.

Thailand's ASEAN neighbor Malaysia, however, is finding ways to improve scientific thinking skills. According to that country's 2015 PISA results, there was a significant improvement for all three domains tested, with science rising 23 points to 443 (Abas \& Shahar, 2016). Also, science, technology, and innovation (STI) are key drivers of sustainable economic growth and social development 
(Thailand Science Technology and Innovation Profile, 2014), with 21 st-century digital skills driving organizations' competitiveness and innovation capacity (Van Laar, Van Deursen, Van Dijk, \& de Haan, 2017).

Many developing nations are beginning to face more problems with students who are not interested in and do not value science. However, in the current climate of rapid technological change, it is becoming imperative - for knowledge workers to acquire $21^{\text {st }}$-century skills (Reeve, 2016), but in Thailand, the production of sufficient, well-trained, and qualified technicians for a quickly changing economy has become a severe problem (UNESCO Bangkok, 2011). The problems with a skilled labor shortage are consistent with Chalamwong et al. (2012), which determined that companies are looking for semi-skilled workers, yet Thai vocational institutions and universities have not been very successful in producing highlyqualified graduates (Kraisuth \& Panjakajornsak, 2017).

Also, according to van Aalderen-Smeets et al. (2012) in primary science education, teachers have not been allowed to develop and conceptualize their ideas and attitudes towards science accurately. This poor theoretical background has led to the use of a multitude of different concepts and measurement instruments. Therefore, research - on factors affecting attitudes concerning science continues to be a crucial element in the discussion of essential motivators contributing to a classroom's atmosphere and activities that increase students' interest in science education. Osborne et al. (2003), even stated that science attitudes' concepts are still quite ambiguous.

Numerous educational projects have attempted to improve or assess attitudes which compose identifiable attributes of scientific thought (van Aalderen-Smeets et al., 2012). One such attempt was research from Çalik, Turan, and Coll (2014), which investigated 1,600 Turkish elementary student teachers' scientific habits of mind. They concluded that it seems accepted school science departments need to equip their students with knowledge of science content and scientific thinking if Turkey is to produce scientifically literate citizens capable of engaging in debate about contemporary sciencebased issues.

According to Simpson and Oliver (1985), researchers have documented that elementary school students receive minimal 
instruction in science, which contributes to the conclusion that many young students enter their first science classes with mixed emotions and ill-prepared about the nature of science. During this crucial period, most students develop their most lasting impressions of science, with many students turning away from science and later becoming a member of a vast number of illiterate adults about science (Miller \& Prewitt, 1979). It is therefore crucial that science educators have accurate research regarding changes in attitudes towards science and their motivation for learning in a student's middle and secondary school years.

Furthermore, there are also a variety of variables that affect students' attitudes. These include students' class grades, gender (ŞAN, İsmail \& İhsan Boran, Ali, 2013; Smith, Pasero, \& McKenna, 2014; Weinburgh, 1995, 2000; Yamtinah, Masykuri, Ashadi, \& Shidiq, 2017), classroom learning activities, classroom size (Gaudet, Ramer, Nakonechny, Cragg, \& Ramer, 2010), cooperative learning (Kose, Sahin, Ergun, \& Gezer, 2010), attitudes and beliefs (Putti, 2011) and classroom management (Ford, 2016). Houseal, Abd-El-Khalick, and Destefano (2014) also investigated Student-Teacher-Scientist Partnerships (STSPs), while ŞAN, İsmail and İhsan Boran, Ali (2013) determined that gifted students aged 12-16 years old did not differ in scientific attitudes when categorized by gender. Scientific attitudes are also crucial to scientific-literacy development (ŞAN, İsmail \& İhsan Boran, Ali, 2013).

The framework for the study's scientific-knowledge assessment, therefore, consisted of correlated factors including, scientific contexts, scientific skills, scientific knowledge, and students' attitudes, such as interest in science, support for science, and responsibility for natural resources and the environment. Due to the importance of a scientific mind, the researchers were interested in studying the factors affecting a student's scientific mind. The study's sample came from secondary school students in Bangkok, Thailand. Understanding the direction and intensity of students' scientific mind allows instructors to predict students' possible behaviors, which helps in proper planning and effective teaching (Miller \& Prewitt, 1979).

According to Bartholomew, Steele, Moustaki, and Galbraith (2008); Hair, Black, Babin, \& Anderson, 2014; Tabachnick and Fidell (2013), a study's measurement model is accessed by use of a confirmatory factor analysis (CFA), followed by structural equation modeling 
(SEM) to determine the overall fit of the proposed model with data and also to identify the relationships among the various constructs. Therefore, CFA was used to investigate the factors of scientific mind as identified from the research literature and theory. Statistical analysis was used to prove the validity of the measurement model, to either accept or reject the studied theory of attributes (Bartholomew et al., 2008; Gagne \& Hancock, 2006; Hair et al., 2014; Mulaik, 2009)

\section{RESEARCH OBJECTIVES}

The study goal was to investigate the construct validity of the scientificmind measurement model among secondary students in Bangkok, Thailand, and the factorloading values of the scientific-mindindicators.

\section{CONCEPTUAL FRAMEWORK}

The measurement model for the paper's scientific mind research came from the synthesis of documents, theory, and related academic and research writings. The results can be summarized as follows:

A scientific mind is the feelings, expressive behaviors, and characteristics of an individual's relationship with science and its terms. These have resulted from emotions developed from experience and learning. It covers interests, attitudes, values, ethics, and expressive behaviors derived from visibly expressing feelings. Attributes that can be used to evaluate scientific mind indicators comprise scientific attitudes and attitudes towards science (Bondebjerg, 2017; Feist, 2006; Fuller, 2016; Hjørland, 2004; Martocchio\&Hertenstein,2003; Varela,Thompson, andRosch(1993).

Scientific attitudes are scientific-thinking patterns or beliefs in science (Gauld, 1982), which are associated with a complex combination of a need to know and to understand. Furthermore, scientific attitudes form an attachment with scientific methods and expressions of a scientific mind, called cognitive orientation (Bondebjerg, 2017). Cognitive orientation is concerned with learning intellect, understanding, and thinking. Varela et al. (1993), also argued that cognitive science is an interaction between cognition, society, and culture. Attributes of scientific attitudes include: 1) curiosity, 2) determination, 3) 
accountability, 4) prudence, 5) honesty, 6) frugality, 7) being broadminded, 8) rationale, and 9) creatively working with other people (Arseculeratne, 2014; Blalock et al., 2008; Feist, 2006; Gauld, 1982; Hjørland, 2004; Martocchio \& Hertenstein, 2003; Moore \& Foy, 1997; Price \& Lee, 2013).

Attitudes towards science are feelings, beliefs, and commitments to the values of scientific works for society or scientists themselves called affective orientation. Attributes of attitudes towards science are covered by 1) interest in science, 2) science value awareness, 3) belief and value about science, and 4) virtue and ethics in science (Barco-Southall, 2012; Chin, 2005; Ornstein, 2006; Osborne et al., 2003; Smith et al., 2014; Sofiani, Maulida, Fadhillah, \& Sihite, 2017; van Aalderen-Smeets et al., 2012).

\section{METHODOLOGY}

\section{Population and Sample}

The population consisted of 19,569 students who were in Grade 8 during the 2016 academic year, from 67 Bangkok schools under the Secondary Educational Service Area Office 1. The sample consisted of 500 students who were in Grade 8 during the 2016 academic year, from Bangkok schools under the Secondary Educational Service Area Office 1. The sample size was determined in accordance with the criteria set forth by Hair et al. (2014) that the sample size should be 100 or higher, the minimum is to have at least five times as the number of variables to be analysis, and the more acceptable sample size would have a 10: 1 ratio. In this scientific-mind measurement model, there were 31 parameters for calculation. The researcher assigned ten samples to each parameter, hence the sample size of $31 \times 10$ (or 310 persons). The larger sample sizes seemed to provide more confidence in CFA results (Bartholomew et al., 2008; Gagne \& Hancock, 2006; Mulaik, 2009; Tabachnick \& Fidell, 2013). So, to reduce the error of power of the tests, the researcher collected data from 500 samples by using a stratified random sampling method.

From an initial population of 67 schools, the schools were divided into sub-groups as follows:

- A Small school had less than 500 students per school. In this category, there were five schools. 
- A Medium school had between 500-1,499 students. In this category, there were 26 schools.

- A large school had between 1,500-2,499 students. In this category, there were 18 schools.

- Extra-large schools had over 2,500 students. In this category, there were 18 schools.

After identification of the sub-groups, simple random sampling was used to select $20 \%$ from each sub-group. From this process, the sample consisted of students from 14 schools which included one small school, five medium schools, four large schools and four extra-large schools. After this, simple random sampling was used to identify $35-$ 36 students, which contributed to the total sample size of 500 students.

\section{Instrument}

The instrument used in this research contained a five-level, Likert type agreement scale to measure the attributes of scientific attitudes and attitudes towards science. Research validity verification used various methods including the use of the Index of Item Objective Congruence (IOC) (Hambleton \& Rovinelli, 1986; Turner \& Carlson, 2003).

Additionally, five experts were tasked to evaluate the content of the survey's items, from which the IOC was used to calculate the results. Items with an IOC of less than 0.50 was rejected. The researchers then conducted a pilot survey in which 57 students who were not participants in the final survey were selected. From this 'try-out,' 40 complete questionnaires were obtained. From this group, 30 were used to test discrimination validity. In the discrimination, respondents' scores were divided into two groups: high and low, for the calculation of t-test values. The level of statistical significance was determined at .05 ( $\square=.05)$, with items having a t-value of 1.76 or above is selected (Agresti \& Finlay, 2014; Carlin, 2001; Eisenhauer, 2008; Kim, 2015; Rasch, Kubinger \& Moder, 2011; Tabachnick $\&$ Fidell, 2013). The attributes of scientific attitudes and attitudes towards science were measured for 15 and 11 items, respectively. Reliability through Cronbach's alpha (Hair et al., 2014), indicated that values for the measurements on attributes of scientific attitudes and attitudes towards science were 0.82 and 0.73 , respectively. 


\section{Variables}

Table 1 shows both the observed and latent variables used in the study. The external latent variable for the study was a student's scientific mind (SCIMIND), which contained the two internal variables of scientific attitudes (SCIAT) and attitudes towards science (ATSCI). Furthermore, for the $1^{\text {st }}$ order CFA analysis, there were a total of 13 variables. This included nine items associated with SCIAT and four items associated with attitudes towards science (ATSCI).

Table 1

External and Internal Variables and their associated Acronyms

\begin{tabular}{|c|c|c|c|c|}
\hline $\begin{array}{c}\text { External } \\
\text { latent } \\
\text { variables }\end{array}$ & $\begin{array}{c}\text { Internal } \\
\text { latent } \\
\text { variables }\end{array}$ & & $\begin{array}{c}\text { Observed variables/ } \\
\text { indicators }\end{array}$ & Acronym \\
\hline \multirow{13}{*}{$\begin{array}{c}\text { Scientific } \\
\text { Mind } \\
\text { (SCIMIND) }\end{array}$} & \multirow{9}{*}{$\begin{array}{l}\text { Scientific } \\
\text { attitudes } \\
\text { (SCIAT) }\end{array}$} & 1) & curiosity & CUR \\
\hline & & 2) & determination & DET \\
\hline & & 3) & accountability & $\mathrm{ACC}$ \\
\hline & & 4) & prudence & PRU \\
\hline & & 5) & honesty & $\mathrm{HON}$ \\
\hline & & $6)$ & frugality & FRU \\
\hline & & 7) & being broad-minded & BEI \\
\hline & & 8) & rationale & RAN \\
\hline & & 9) & $\begin{array}{l}\text { creatively working with } \\
\text { other people }\end{array}$ & CRE \\
\hline & \multirow{4}{*}{$\begin{array}{c}\text { Attitudes } \\
\text { towards } \\
\text { science } \\
\text { (ATSCI) }\end{array}$} & 1) & interest in science & INS \\
\hline & & 2) & science value awareness & SVA \\
\hline & & 3) & $\begin{array}{l}\text { belief and value about } \\
\text { science }\end{array}$ & BVS \\
\hline & & 4) & $\begin{array}{l}\text { virtue and ethic in } \\
\text { science }\end{array}$ & VES \\
\hline
\end{tabular}

\section{Data Collection}

Researchers collected data from the sample of 500 students who were in Grade 8 for the 2016 academic year, from Bangkok schools under the Secondary Educational Service Area Office 1, via measurement 
on attributes of scientific attitudes (SCIAT) and attitudes towards science (ATSCI).

Between November 2016 to January 2017, 14 school administrators and teachers were contacted to gain permission for access to the school and students. The researchers then conducted the survey in which 1-2 days in each institution was allocated to review and collect the student questionnaires.

\section{Data Analysis}

1. The data were analyzed using descriptive statistics including mean $(\overline{\mathrm{X}})$ and standard deviation (S.D.).

2. Pearson's product moment correlation coefficient (PPMC) was analyzed among the observed variables to determine the size and direction of the observed variables in the model, and the relationship between them.

3. Appropriateness of data and the relationship between variables in factor analysis were examined using the Bartlett test of sphericity (Hair et al., 2014). The Kaiser-Meyer-Olkin (KMO) test was also used to show how well the data is suited (Cerny \& Kaiser, 1977).

4. Construct validity of the scientific-attitudes measurement model and construct validity of attitudes towards the science measurement model were investigated by analyzing the first-order confirmatory factor analysis (CFA). Furthermore, construct validity of the scientific-mind measurement model was investigated by use of an additional secondorder confirmatory factor analysis ( $2^{\text {nd }}$ order CFA). Software analysis was undertaken with the use of SPSS AMOS Version 23 software. Standardized loading estimates were required to be higher than .5 (Hair et al., 2014), with parameter estimation accomplished by the use of the Maximum Likelihood (ML) method and the variance-covariance matrix (Bartholomew et al., 2008; Tabachnick \& Fidell, 2013). The model's goodness of fit used indices including Chi-square $\left(\chi^{2}\right)$, the goodness-of-fit index (GFI), the root mean square error of approximation (RMSEA) and the root mean square residual (RMR) (Bartholomew et al., 2008; Hair et al., 2014; Hooper, Coughlan, \& Mullen, 2008; Tabachnick \& Fidell, 2013). 


\section{RESULTS}

\section{Results on Construct Validity Testing of the Scientific- Attitudes Measurement Model from the First-Order CFA}

Scientific attitudes (SCIAT) consisted of nine indicators, as shown in Figure 1. The means were 3.600-3.858, and standard deviations were 0.751-1.007, which indicated that students possessed all attributes of scientific attitudes at a high level (Mean $=3.51-4.50)$.

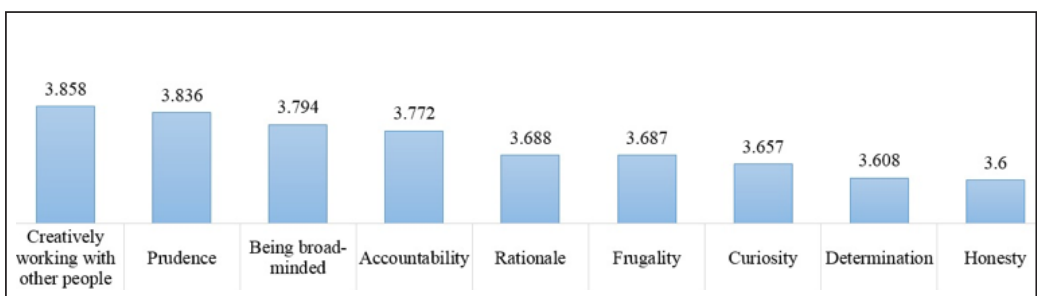

Figure 1. Means of indicators as factors of scientific attitudes.

Table 2

Means, Standard Deviations, and Correlation Coefficients of Observed Variables or Indicators in the Scientific-Attitudes Measurement Model for Students $(n=500)$

\begin{tabular}{|c|c|c|c|c|c|c|c|c|c|}
\hline \multirow{2}{*}{$\begin{array}{l}\text { Observed } \\
\text { variables }\end{array}$} & \multicolumn{9}{|c|}{ Correlation coefficient } \\
\hline & CUR & DET & ACC & PRU & HON & FRU & BEI & RAN & CRE \\
\hline CUR & 1.000 & & & & & & & & \\
\hline DET & $0.63 * *$ & 1.000 & & & & & & & \\
\hline ACC & $0.47 * *$ & $0.42 * *$ & 1.000 & & & & & & \\
\hline PRU & $0.52 * *$ & $0.50^{* *}$ & $0.44 * *$ & 1.000 & & & & & \\
\hline $\mathrm{HON}$ & $0.50 * *$ & $0.42^{* *}$ & $0.32 * *$ & $0.51 * *$ & 1.000 & & & & \\
\hline FRU & $0.48 * *$ & $0.41 * *$ & $0.42 * *$ & $0.47 * *$ & $0.45^{* *}$ & 1.000 & & & \\
\hline BEI & $0.32 * *$ & $0.31 * *$ & $0.37 * *$ & $0.39 * *$ & $0.26 * *$ & $0.46 * *$ & 1.000 & & \\
\hline RAN & $0.45^{* *}$ & $0.40^{* *}$ & $0.36 * *$ & $0.47 * *$ & $0.40 * *$ & $0.46 * *$ & $0.46 * *$ & 1.000 & \\
\hline CRE & $0.42 * *$ & $0.42 * *$ & $0.50 * *$ & $0.49 * *$ & $0.39^{* *}$ & $0.47 * *$ & $0.53 * *$ & $0.55^{* *}$ & 1.000 \\
\hline Mean & 3.657 & 3.608 & 3.772 & 3.836 & 3.600 & 3.687 & 3.794 & 3.688 & 3.858 \\
\hline $\begin{array}{c}\text { Std. } \\
\text { Deviation }\end{array}$ & 0.827 & 0.982 & 1.007 & 0.792 & 0.781 & 0.751 & 0.928 & 0.792 & 0.816 \\
\hline
\end{tabular}

Note. ${ }^{*} \mathrm{p}<$ <.01, KMO: Kaiser-Meyer-Olkin measure of sampling adequacy $=0.904$ Bartlett's test of sphericity: Chi-Square $=1,749.589, \mathrm{df}=36, \mathrm{p}=.000$ 
Table 2 shows the results from the PPMC analysis. The PPMC is used to calculate the strength and direction between the model's variables. From the analysis, all nine indicators yielded the result that the correlation for all 36 pairs of indicators significantly differed from zero, at a statistical significance level of .01. Additionally, all pairs had positive correlation values, with correlation coefficients between $0.26-0.63$. Bartlett's test of sphericity returned a Chi-square value $=1,749.589, \mathrm{df}=36$, and $\mathrm{p}=.000$, which was significantly different from zero at a statistical significance level of .01 . The results were also consistent with the Kaiser-Meyer-Olkin (KMO) index analysis, which equaled 0.904 , which was high enough to use for analyzing construct validity factors (Tabachnick \& Fidell, 2013).

Table 3

Statistical Analysis of Construct Validity Testing of the Scientific-Attitudes Measurement Model for Students $(n=500)$

Indicators as factors of Scientific attitudes

\begin{tabular}{cccccc}
$\begin{array}{c}\text { Observed } \\
\text { variables }\end{array}$ & $\mathrm{b}_{\mathrm{sc}}$ & $\mathrm{S} . \mathrm{E}$. & $\mathrm{t}$ & $\begin{array}{c}\text { Factor } \\
\text { score } \\
\text { weights } \\
(\mathrm{FS})\end{array}$ & $\begin{array}{c}\text { Squared } \\
\text { multiple } \\
\text { correlations } \\
\left(\mathrm{R}^{2}\right)\end{array}$ \\
\hline CUR & $0.719 * *$ & $<-->$ & $<->$ & 0.126 & 0.518 \\
$\mathrm{DET}$ & $0.650^{* *}$ & 0.067 & 16.050 & 0.067 & 0.422 \\
$\mathrm{ACC}$ & $0.625^{*} *$ & 0.085 & 12.418 & 0.097 & 0.390 \\
$\mathrm{PRU}$ & $0.735^{*} *$ & 0.066 & 14.792 & 0.171 & 0.540 \\
$\mathrm{HON}$ & $0.666^{* *}$ & 0.066 & 13.315 & 0.151 & 0.443 \\
FRU & $0.672^{*}$ & 0.062 & 13.611 & 0.134 & 0.451 \\
$\mathrm{BEI}$ & $0.497 * *$ & 0.077 & 10.019 & 0.016 & 0.247 \\
$\mathrm{RAN}$ & $0.627 * *$ & 0.066 & 12.711 & 0.089 & 0.394 \\
$\mathrm{CRE}$ & $0.638^{* *}$ & 0.068 & 12.775 & 0.065 & 0.407
\end{tabular}

Note. ${ }^{*} \mathrm{p} \mathrm{p}<.01, \mathrm{~b}_{\mathrm{sc}}=$ Factor Loading Values, $<-->=$ Fixed parameters do not report S.E. and t. Chi-square $=29.779, \mathrm{df}=20, \mathrm{p}=0.074, \chi^{2} / \mathrm{df}=1.489$, RMSEA $=0.031, \mathrm{RMR}=0.017, \mathrm{GFI}=0.987, \mathrm{AGFI}=0.971$

Table 3 shows the results of the construct validity testing of the scientific-attitudes (SCIAT) measurement model, whose results indicated the model's consistency with the empirical data. Confirmation of this was from a Chi-square value $=29.779$, $\mathrm{df}=20$, and $p=0.074$. According to Hooper et al. (2008), reporting the Chisquare test with its degree of freedom and the associated $\mathrm{p}$-value is 
mandatory, with a value as low as 2.0 stated as acceptable (Tabachnick $\&$ Fidell, 2013).Additionally, $\chi^{2}$ differed from zero with no statistical significance. Moreover, RMSEA $=0.031$ and $\mathrm{RMR}=0.017$, which were close to $0 ; \mathrm{GFI}=0.987$ and the AGFI $=0.971$, which were close to 1 . The $\chi^{2} / \mathrm{df}=1.489$, which was less than 2; and the factor loading values of all indicators differed significantly from zero at a statistical significance level of .01. The squared multiple correlations $\left(\mathrm{R}^{2}\right)$ of all indicators ranged from 0.247-0.540 (Table 3). Finally, the scientific-attitudes measurement model is shown in Figure 2.

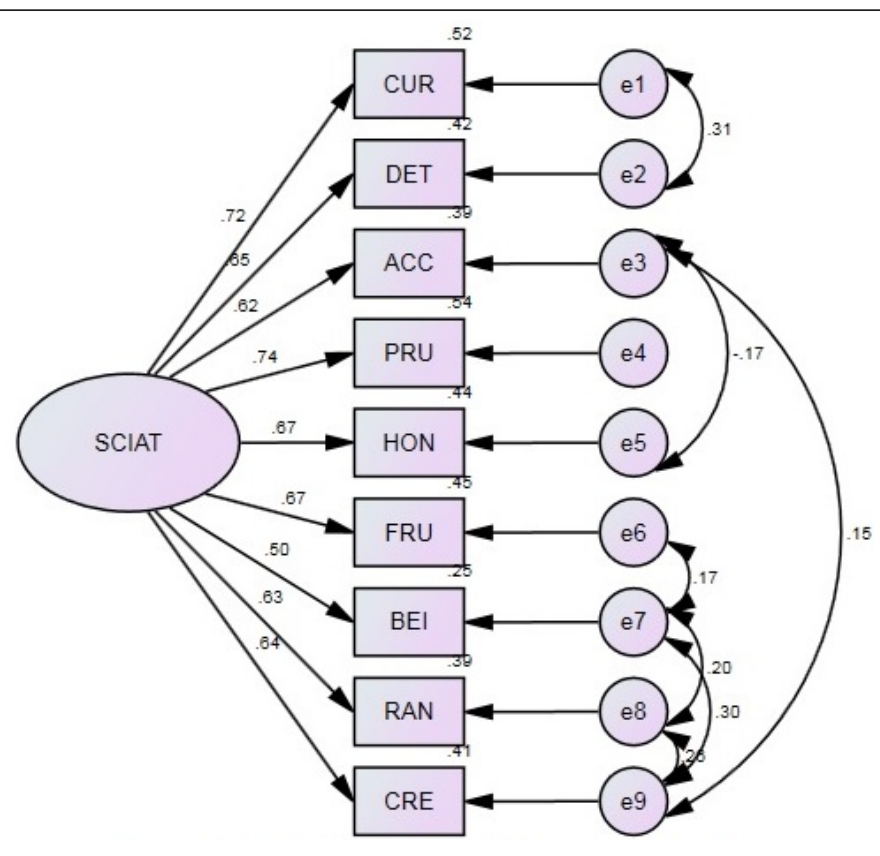

Figure 2. Scientific-attitudes measurement model Note. Chi-square $=29.779, \chi^{2} / \mathrm{df}=1.489, \mathrm{df}=20, \mathrm{p}$-value $=0.074$, $\mathrm{GFI}=0.987, \mathrm{CFI}=0.994, \mathrm{RMR}=0.017, \mathrm{RMSEA}=0.031$.

\section{Results on Construct Validity Testing of Attitudes towards the Science Measurement Model from the $1^{\text {st }}$-Order CFA}

Attitudes towards science (ATSCI) consisted of four indicators, as shown in Figure 3. The means were from 3.857-4.024, and standard deviations were from $0.580-0.814$, which indicated that students possessed all attributes of attitudes towards science at a high level (Mean $=3.51-4.50)$. 




Table 4

Means, Standard Deviations, and Correlation Coefficients of Observed Variables or Indicators in the Attitudes towards Science (ATSCI) Measurement Model for Students $(n=500)$

\section{Correlation coefficient}

Observed

variables

INS

SVA

BVS

VES

\begin{tabular}{ccccc}
\hline INS & 1.000 & & & \\
SVA & $0.46^{* *}$ & 1.000 & & \\
BVS & $0.23^{* *}$ & $0.45^{* *}$ & 1.000 & \\
VES & $0.36^{* *}$ & $0.47^{* *}$ & $0.32^{* *}$ & 1.000 \\
Mean & 3.879 & 4.024 & 4.002 & 3.857 \\
Std. Deviation & 0.752 & 0.580 & 0.814 & 0.710 \\
\hline
\end{tabular}

Note. ${ }^{* *} \mathrm{p}<.01$, KMO: Kaiser-Meyer-Olkin Measure of Sampling adequacy $=0.717$, Bartlett's test of sphericity: Chi-Square $=379.955$, $\mathrm{df}=6, \mathrm{p}=.000$

Table 4 shows the results from the PPMC analysis. From the PPMC analysis of the four indicators, and their associated six pairs of correlations, the indicators were shown to significantly differ from zero, at a statistical significance level of .01. All pairs also had positive correlation values, with correlation coefficients from $0.23-0.47$, as shown in Table 4. Bartlett's test of sphericity returned a Chi-square value $=379.955, \mathrm{df}=6$, and $\mathrm{p}=.000$, which was significantly different from zero at a statistical significance level of .01 . This was also consistent with the result of the 
Kaiser-Meyer-Olkin (KMO) index analysis, which equaled 0.717. The value near 1 indicated that the correlation matrix of the observed variable or of the indicator was not a unit matrix, and the correlation between variables was high enough to use for analyzing construct validity factors.

Table 5

Statistical Analysis of Construct Validity Testing of Attitudes towards Science (ATSCI) Measurement Model for Students $(n=500)$

Indicators as factors of Attitudes towards science

\begin{tabular}{cccccc}
$\begin{array}{c}\text { Observed } \\
\text { variables }\end{array}$ & $\mathrm{b}_{\mathrm{sc}}$ & $\mathrm{S} . \mathrm{E}$. & $\mathrm{t}$ & $\begin{array}{c}\text { Factor score } \\
\text { weights } \\
(\mathrm{FS})\end{array}$ & $\begin{array}{c}\text { Squared } \\
\text { multiple } \\
\text { correlations } \\
\left(\mathrm{R}^{2}\right)\end{array}$ \\
\hline INS & $0.590 * *$ & $<-->$ & $<->$ & 0.143 & 0.348 \\
SVA & $0.789 * *$ & 0.109 & 9.425 & 0.367 & 0.623 \\
BVS & $0.559 * *$ & 0.120 & 8.551 & 0.121 & 0.313 \\
VES & $0.594 * *$ & 0.102 & 9.282 & 0.132 & 0.353 \\
\hline
\end{tabular}

Note. $* * \mathrm{p}<.01, \mathrm{~b}_{\mathrm{sc}}=$ Factor loading values, $<-->=$ Fixed Parameters do not report S.E. and t.Chi-square $=0.413, \mathrm{df}=1, \mathrm{p}=0.520, \chi^{2} / \mathrm{df}=$ $0.413, \mathrm{RMSEA}=0.000, \mathrm{RMR}=0.003, \mathrm{GFI}=1.000, \mathrm{AGFI}=0.996$



Figure 4. Attitudes towards the science measurement model Note. Chi-square $=0.413, \chi^{2} / \mathrm{df}=0.413, \mathrm{df}=1, \mathrm{p}$-value $=$ $0.520, \mathrm{GFI}=1.000, \mathrm{CFI}=1.000, \mathrm{RMR}=0.003, \mathrm{RMSEA}=$ 0.0 . 
Table 5 shows the results on construct validity testing of the attitudes towards science (ATSCI) measurement model. From it, the model was shown to be consistent with the empirical data, as Chi-square value $=$ 0.413 , $\mathrm{df}=1$, and $\mathrm{p}=0.520$. Also, $\chi^{2}$ differed from zero with no statistical significance. Moreover, RMSEA $=0.000$ and $\mathrm{RMR}=0.003$, which were close to 0 . The values for GFI $=1.000$ and AGFI $=0.996$, which were close to 1 . The value for $\chi^{2} / \mathrm{df}=0.413$, which was less than 2 , with the factor loading values of all indicators differing significantly from zero at a statistical significance level of .01 . Table 5 also shows the squared multiple correlations $\left(\mathrm{R}^{2}\right)$ of all indicators ranged from 0.313-0.623. Figure 4 presents the attitudes towards science (ATSCI) measurement model.

\section{Results on Construct Validity Testing of the Scientific-Mind (SCIMIND) Measurement Model from the $2^{\text {nd }}$ Order CFA}

The external latent variable was a scientific mind (SCIMIND). It consisted of two indicators, namely, scientific attitudes (SCIAT) and attitudes towards science (ATSCI). The internal latent variables included SCIAT and ATSCI. SCIAT consisted of 9 variables including, 1) curiosity (CUR), 2) determination (DET), 3) accountability (ACC), 4) prudence (PRU), 5) honesty (HON), 6) frugality (FRU), 7) being broad-minded $(\mathrm{BEI}), 8)$ rationale (RAN), and 9) creatively working with other people (CRE). Moreover, ATSCI consisted of 4 variables including 1) interest in science (INS), 2) science value awareness (SVA), 3) belief and value about science (BVS), and 4) virtue and ethics in science (VES)

Table 6 shows the mean of SCIMIND was 3.789 and the standard deviation was 0.536 , indicating that students had a high level of scientific mind. Once classified according to each indicator, the mean of students' SCIAT was 3.722 , and the standard deviation was 0.593 , while the mean of students' ATSCI was 3.950, and the standard deviation was 0.513, indicating that students had a good SCIAT and ATSCI.

The PPMC analysis among all 13 indicators yielded the result that the correlation of all 91 pairs of indicators significantly differed from zero, at a statistical significance level of .01 . Additionally, all pairs had positive correlation values, with correlation coefficients from $0.20-0.88$, as shown in Table 6. Bartlett's test of sphericity returned a Chi-square value $=$ $2,482.473$, $\mathrm{df}=78$, and $\mathrm{p}=.000$, which was significantly different from zero at a statistical significance level of .01. This was also consistent with the result of the KMO index analysis, which equaled 0.927 . The value near 1 indicated that the correlation matrix of the observed variable or of the indicator was not a unit matrix, and the correlation between variables was high enough to use for analyzing construct validity factors. 


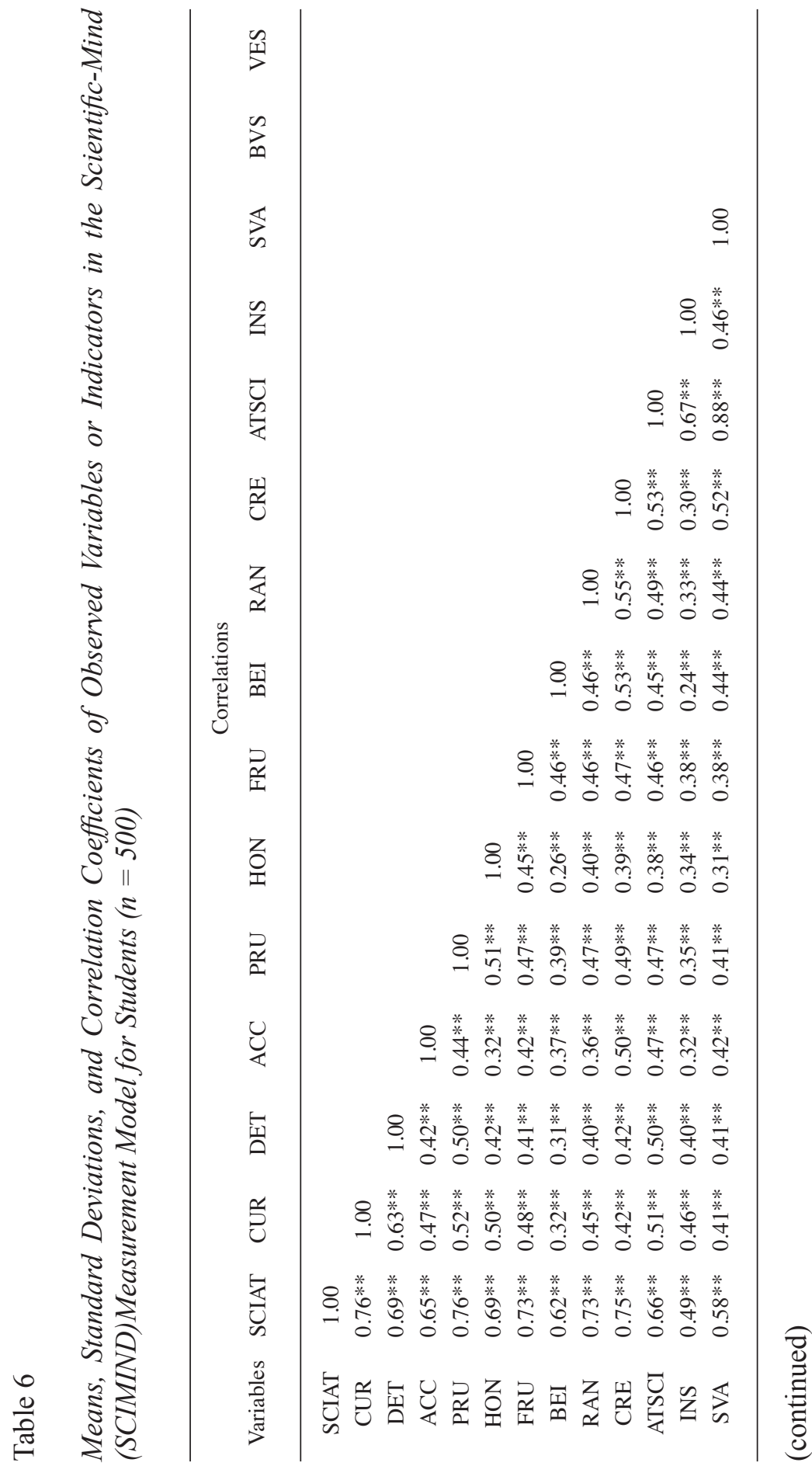




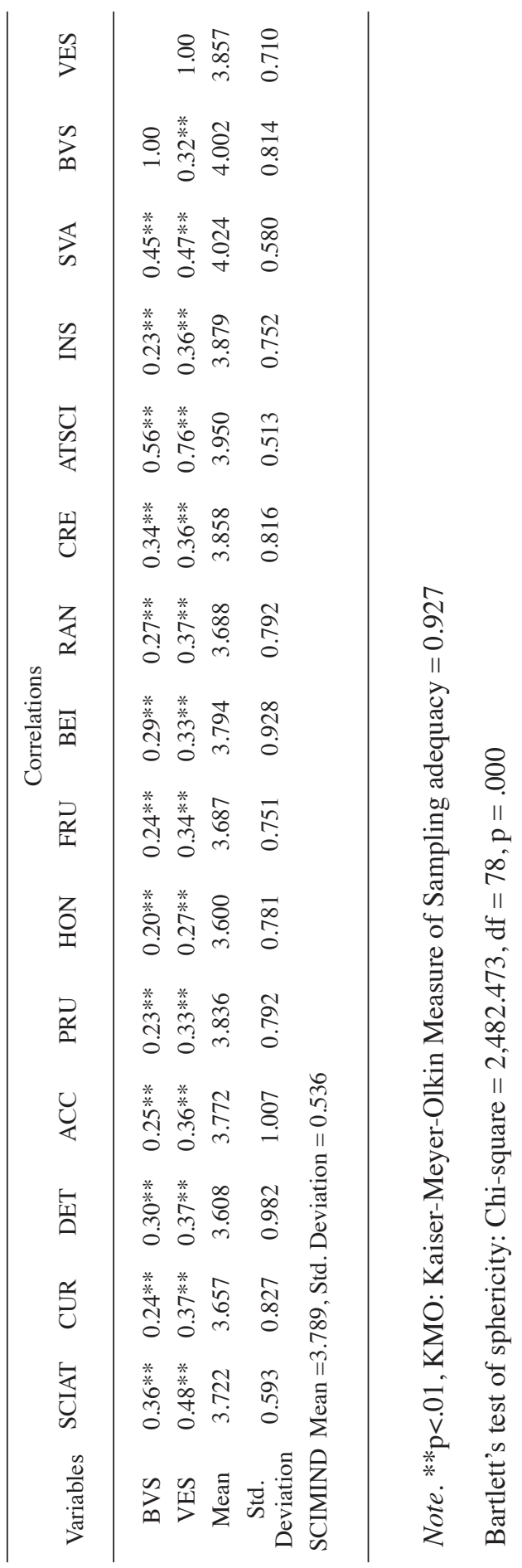


Table 7 shows the results on construct validity testing of the scientificmind measurement model indicated the model's consistency with empirical data, which could be considered from a Chi-square value $=56.535, \mathrm{df}=47$, and $\mathrm{p}=0.161$. Also, $\chi^{2}$ differed from zero with no statistical significance. Moreover, RMSEA $=0.020$ and $\mathrm{RMR}=0.0018$, which were close to 0 . The values for GFI $=0.983$ and AGFI $=0.967$, which were close to 1 . The value for $\chi^{2} / \mathrm{df}=1.203$, which was less than 2 , with the factor loading values of all indicators differing significantly from zero at a statistical significance level of .01. The squared multiple correlations $\left(\mathrm{R}^{2}\right)$ of all indicators ranged from $0.277-0.969$. Figure 5 shows the factor loading values of scientific mind (SCIMIND) attributes.

Table 7

Statistical Analysis of Construct Validity Testing of ScientificMind (SCIMIND) Measurement Model for Students $(n=500)$

\begin{tabular}{|c|c|c|c|c|c|}
\hline Variables & $\mathrm{b}_{\mathrm{sc}}$ & $\begin{array}{l}\text { Indica } \\
\text { S.E. }\end{array}$ & rs as fact & $\begin{array}{l}\text { s of Scien } \\
\text { Factor } \\
\text { score } \\
\text { weights } \\
\text { (FS) }\end{array}$ & $\begin{array}{l}\text { ic mind } \\
\text { Squared multiple } \\
\text { correlations }\left(\mathrm{R}^{2}\right)\end{array}$ \\
\hline \multicolumn{6}{|c|}{ First-order confirmatory factor analysis } \\
\hline \multicolumn{6}{|l|}{ SCIAT } \\
\hline CUR & $0.703 * *$ & $<-->$ & $<->$ & 0.183 & 0.495 \\
\hline DET & $0.647 * *$ & 0.070 & 15.750 & 0.097 & 0.419 \\
\hline ACC & $0.660 * *$ & 0.088 & 13.073 & 0.172 & 0.436 \\
\hline PRU & $0.700 * *$ & 0.069 & 13.941 & 0.208 & 0.490 \\
\hline $\mathrm{HON}$ & $0.560 * *$ & 0.063 & 11.968 & 0.052 & 0.314 \\
\hline FRU & $0.659 * *$ & 0.065 & 13.192 & 0.185 & 0.434 \\
\hline BEI & $0.538 * *$ & 0.081 & 10.611 & 0.010 & 0.290 \\
\hline RAN & $0.674 * *$ & 0.070 & 13.101 & 0.205 & 0.455 \\
\hline CRE & $0.710 * *$ & 0.075 & 13.357 & 0.190 & 0.503 \\
\hline \multicolumn{6}{|l|}{ ATSCI } \\
\hline INS & $0.599 * *$ & $<-->$ & $<-->$ & 0.012 & 0.358 \\
\hline SVA & $0.782 * *$ & 0.086 & 11.723 & 0.179 & 0.612 \\
\hline BVS & $0.526 * *$ & 0.108 & 8.825 & 0.062 & 0.277 \\
\hline VES & $0.617 * *$ & 0.094 & 10.372 & 0.095 & 0.381 \\
\hline \multicolumn{6}{|c|}{ Second-order confirmatory factor analysis } \\
\hline SCIAT & $0.985 * *$ & $<-->$ & $<-->$ & - & 0.969 \\
\hline ATSCI & $0.805 * *$ & 0.044 & 8.192 & - & 0.648 \\
\hline
\end{tabular}

Note. ${ }^{*} \mathrm{p}<.01, \mathrm{~b}_{\mathrm{sc}}=$ Factor loading values, $<-->=$ Fixe.d parameters do not report S.E. and t. Chi-square $=56.535, \mathrm{df}=47, \mathrm{p}=0.161, \chi^{2} / \mathrm{df}=1.203, \mathrm{RMSEA}=$ $0.020, \mathrm{RMR}=0.018, \mathrm{GFI}=0.983, \mathrm{AGFI}=0.967$ 


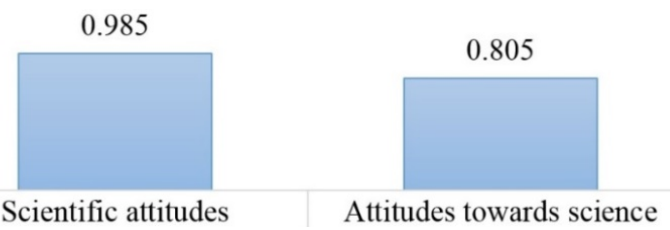

Figure 5. Factor loading values of scientific mind attributes.

Descending factor-loading values of the attributes of SCIAT and ATSCI are shown in Figure 6. In addition, the SCIMIND measurement model utilizing $2^{\text {nd }}-$ order CFA, consisting of the variables shown in Figure 7.

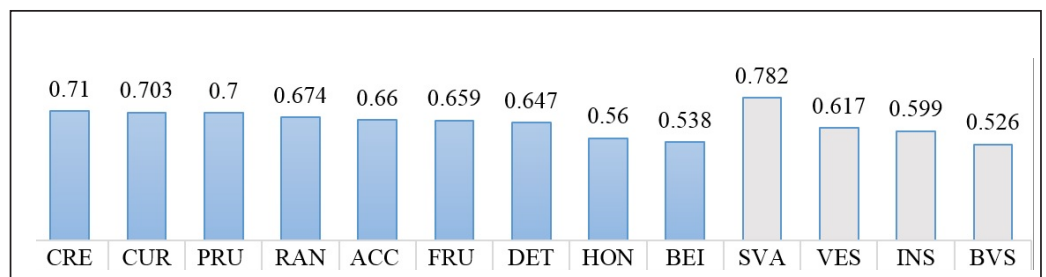

Figure 6. Factor loading values of SCIAT and ATSCI attributes.

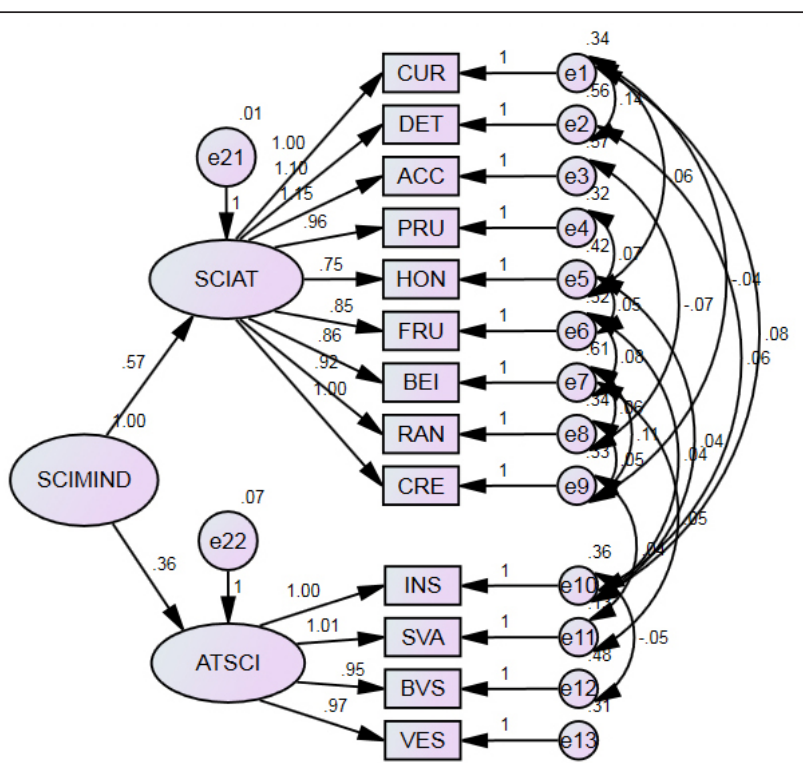

Figure 7. The SCIMIND measurement model.

Note. Chi-square $=56.535, X^{2} / \mathrm{df}=1.203, \mathrm{df}=47, \mathrm{p}$-value $=0.161, \mathrm{GFI}=$ $0.983, \mathrm{CFI}=0.996, \mathrm{RMR}=0.018, \mathrm{RMSEA}=0.020$ 


\section{DISCUSSION}

Research findings suggest that students possessed a high level of all attributes of scientific attitudes (SCIAT) and attitudes towards science (ATSCI). This result was somewhat different from a similar study in Indonesia, in which Sofiani et al. (2017), indicated that science students had a moderate attitude towards science, with little attitude difference between male and female students. However, in the Philippines, Lacap (2015) determined that science major students have high attitudes in terms of open-mindedness, aversion to superstitions, curiosity, and objectivity, while moderate in terms of suspended judgment and rationality.

From the Organisation for Economic Co-operation and Development (OECD) 2015 PISA report (Volume III), it was reported that student anxiety about schoolwork, homework, and tests is negatively related to performance, but teachers can do much to help with this problem (OECD, 2017). If science teachers provide individual help, students are also less likely to report anxiety. This suggests small classroom sizes can be a benefit to better scientific understanding and scores, which is consistent with Gaudet et al. (2010) which suggested classroom size has a direct effect on academic performance and student attitudes.

The 2015 PISA report also suggests that science educators need to help their students better understand their own strengths and weaknesses, while also building an awareness of what they can do to lessen those weaknesses (OECD, 2017). The design of assessment tests also matters, with easier to more difficult assessments building students' sense of control. It also gives students the opportunity to show their skills in a test of less importance before taking a test of greater importance.

The development of students' scientific mind, therefore, remains critical, particularly for Thai students as their scores continue to decline. According to the OECD (2016), Thai student scores in science and reading have declined significantly since 2012, dropping from 444 to 421 and 441 to 409 , respectively. Also, according to the OECD, about $50 \%$ of Thai students are below basic proficiency levels in science, reading, and math.

This study, however, showed that the promotion of SCIMIND indicated that the creatively working with other people $\left(\mathrm{CRE}, \mathrm{b}_{\mathrm{sc}}=\right.$ 
0.710) indicator had the highest factor loading values of all nine variables for scientific attitudes. Therefore, students should be encouraged to use their social skills and interact with others, as well as be encouraged in their innovative expression. The study's results were also consistent with research from Singapore, in which nurturing creative and critical thinking involves the classroom environment, as well as teacher competencies and dispositions (Leen, Hong, Kwan, \& Ying, 2016). A science classroom's atmosphere affects creativity, skepticism, and enthusiasm in finding solutions (Trnova \& Trna, 2014).

Furthermore, global research has suggested that the science classroom can be transformed with the use of the Science Writing Heuristic (SWH) approach (Putti, 2011). In Korea, by use of SWH techniques, teachers modify their old style labs and memorization, to a more real-world environment similar to what actual scientist undertake (Nam, Choi, \& Hand, 2011). Shin, Choi, and Park (2013) in Korea also evaluated SWH in the science classroom and reported it was helpful for students in finding big ideas, comprehension of science concepts, development of logical thinking abilities, and increasing academic scores. Furthermore, students learn to negotiate meaning, they pose better research questions, gather data, and generate claims based on evidence. Also, language, both oral and written, is paramount to this approach. The emphasis, therefore, is on understanding and practicing science, not memorizing scientific facts (Shin et al., 2013).

Also, theSmall-GroupLearning(SGL) model of learning management has characteristics which support effective learning in science classrooms (Gaudetet al.,2010). Science classroom conditions such as those of demonstration equipment and physical facilities are related to students' attitudes (Ford, 2016). Also, the self-conception of science, science achievement, learning environment, scientific-achievement motivation, and family environment affect a student's scientific mind.

Furthermore, from the SCIMIND model, ATSCI's science value awareness indicator $\left(S V A: b_{s c}=0.782\right)$ had the highest factor loading value. This appears to imply that students should be encouraged to be aware of and appreciate the benefits of science. In addition, the indicator with the second-highest factor loading value was virtue and ethics in science (VES: $b_{\text {sc }}=0.617$ ). Thus, students should be urged to behave well in relation to science, and apply science to 
their consideration and practice. The indicator with the lowest factor loading value was belief and value about science (BVS: $b_{\text {sc }}=0.526$ ), which referred to a person's information, opinions, and beliefs in science and/or the relevance of science. In terms of the learning management approach to students' scientific-mind development, research indicated that scientific inquiry, cooperative learning, and context-based learning, affected the promotion of a student's scientific mind and attitudes (Maxwell, Lambeth, \& Cox, 2015),

According to Houseal et al. (2014), scientific inquiry can also be effectively taught by authentic science experiences through collaboration among students, teachers, and scientists, in order to promote students' attitudes. This allows students to gain a better knowledge of scientists and improve their perceptions and attitudes of scientists. Further research from Malaysia by Srikoon, Bunterm, Nethanomsak, and Ngang (2017), indicated that a neurocognitivebased model (5P) of learning management affected students' interests more than the conventional contextualized model (5E) of learning management. Anderson (2009) also suggested that there be a synthesis of neurocognitive learning theory and the constructivist philosophy of science teaching and learning to improve the attention of learners. The latter has already become a major guiding model for instructional design in many disciplines (Srikoon et al., 2017). Also, socio-scientific issues (SSIs) are used to improve scientific literacy related to students' rationality, analytical decisions, and synthesis and evaluation of data (Çalik et al., 2014).

Heng, Surif, Seng, and Ibrahim (2015) took a different approach to what is central to science education. According to their research, argumentative practices have recently been emphasized in Malaysian schools as a method to promote students' reasoning skills and to develop a student's understanding of scientific concepts.

Mecit (2006) adopted the seven-phase (7E) learning cycle model to study the inquiry-based learning methods used in improving Turkish students' critical thinking skills. The 7E learning cycle model is comprised of the elements eliciting, engaging, exploring, explaining, elaboration, evaluating, and extending (Eisenkraft, 2003). It was determined that the use of the inquiry-based learning improved Turkish students' critical thinking skills. Kose et al. (2010) on the other hand, suggested that effective teaching and learning of science depends on the selected teaching method touching students' most 
learning senses, and suggested a method of cooperative learning for the sample group of eighth-grade students' achievement and attitude toward science.

\section{CONCLUSION}

The testing of the scientific-mind measurement model for secondary school students in Bangkok was consistent with empirical data. The scientific-mind factors consisted of two indicators, i.e., scientific attitudes (SCIAT) and attitudes towards science (ATSCI). The indicator with the highest factor loading values among the scientific-mind (SCIMIND) factors was SCIAT, followed by ATSCI.

Scientific-attitudes (SCIAT) factors included nine indicators sorted by factor loading values from the highest to lowest. These included: 1 ) creatively working with other people (CRE, $\left.\left.b_{\text {sc }}=0.710\right), 2\right)$ curiosity (CUR, $\left.\mathrm{b}_{\mathrm{sc}}=0.703\right), 3$ ) prudence (PRU, $\left.\mathrm{b}_{\mathrm{sc}}=0.700\right)$, 4) rationale (RAN, $\left.\left.b_{\mathrm{sc}}=0.674\right), 5\right)$ accountability (ACC, $\left.\left.\mathrm{b}_{\mathrm{sc}}=0.660\right), 6\right)$ frugality (FRU, $\left.b_{\text {sc }}=0.659\right), 7$ ) determination (DET, $\left.b_{\text {sc }}=0.647\right), 8$ ) honesty $\left(\mathrm{HON}, \mathrm{b}_{\mathrm{sc}}=0.560\right)$, and 9) being broad-minded (BEI, $\left.\mathrm{b}_{\mathrm{sc}}=0.538\right)$,

Factors of attitudes towards science (ATSCI) included four indicators. Sorted by factor loading values from the highest to lowest, these included: 1) science value awareness (SVA, $\left.\left.\mathrm{b}_{\mathrm{sc}}=0.782\right), 2\right)$ virtue and ethics in science (VES, $\left.b_{s c}=0.617\right), 3$ ) interest in science (INS, $\left.\mathrm{b}_{\mathrm{sc}}=0.599\right)$, and belief and value about science (BVS, $\mathrm{b}_{\mathrm{sc}}=0.526$ ).

\section{ACKNOWLEDGEMENT}

Great appreciation goes to school administrators, science teachers, and students who were in Grade 8 during the 2016 academic year at Bangkok schools under the Secondary Educational Service Area Office 1, for their support in producing the data used in this research.

\section{REFERENCES}

Abas, A., \& Shahar, F. M. (2016, December 6). PISA 2015: Malaysia shows significant improvement in math, science \& reading. New Straits Times. Retrieved from https://tinyurl.com/ y7lx4okn 
Agresti, A., \& Finlay, B. (2014). Statistical methods for the social sciences (4th ed.). Harlow: Pearson.

American Association for the Advancement of Science. (1993). Benchmarks for science literacy, Project 2061. New York, NY: Oxford University Press.

Anderson, O. R. (2009). Neurocognitive theory and constructivism in science education: A review of neurobiological, cognitive and cultural perspectives. Brunei International Journal of Science \& Mathematics Education, 1(1), 1-32. Retrieved from https://tinyurl.com/yajhfhj2

Arnold, D. H., Fisher, P. H., Doctoroff, G. L., \& Dobbs, J. (2002). Accelerating math development in head start classrooms. Journal of Educational Psychology, 94(4), 762-770. https:// doi.org/10.1037//0022-0663.94.4.762

Arseculeratne, SN. (2014). The scientific attitude (the scientific temper) in Eastern and Western societies. Anuradhapura Medical Journal, 8(1), 22-29. http://dx.doi.org/10.4038/amj. v8i1.6757

Barco-Southall, C. (2012). A correlation study of student attitudes toward science in a Southern State high school (Doctoral dissertation). Nova Southeastern University, Retrieved from http://adsabs.harvard.edu/abs/2012PhDT.......388B

Bartholomew, D. J., Steele, F., Moustaki, I., \& Galbraith, J. I. (2008). Analysis of multivariate social science data (2nd ed.). Boca Raton, Fl: CRC Press.

Blalock, C. L., Lichtenstein, M. J., Owen, S., Pruski, L., Marshall, C., \& Toepperwein, M. A. (2008). In pursuit of validity: A comprehensive review of science attitude instruments 19352005. International Journal of Science Education, 30(7), 961977. http://dx.doi.org/10.1080/09500690701344578

Bondebjerg, Ib. (2017). The creative mind: Cognition, society, and culture. Palgrave Communications, 3(1). https://doi. org/10.1057/s41599-017-0024-1

Brearton, M. A. (1996). Update on Project 2061: A comparison of project 2061 \& National Science Education Standards. School Science and Mathematics, 96(5), 276-276. https://doi.org/10.1111/j.1949-8594.1996.tb10243.x

Çalik, M., Turan, B., \& Coll, R. K. (2014). A cross-age study of elementary student teachers' scientific habits of mind concerning socioscientific issues. International Journal of Science and Mathematics Education, 12(6), 1315-1340. https://doi.org/10.1007/s10763-013-9458-0 
Carlin. JB., \& Doyle, LW. (2001). 4: Basic concepts of statistical reasoning: Hypothesis tests and the $t$-test. Journal of Paediatrics and Child Health, 37(1), 72-77. https://doi. org/10.1046/j.1440-1754.2001.00634.x

Cerny, B. A., \& Kaiser, H. F. (1977). A study of a measure of sampling adequacy for factor- analytic correlation matrices. Multivariate Behavioral Research, 12(1), 43-47. https://doi. org/10.1207/s15327906mbr1201_3

Chalamwong, Y., Hongprayoon, K., Suebnusorn, W., Doung, N. A., Chan, S., \& Dyna, H. (2012). Skills for employability: Southeast Asia. Thailand Development Research Institute (TDRI). Retrieved from http://tinyurl.com/kk3s64e

Chin, C.-C. (2005). First-year pre-service teachers in Taiwan-Do they enter the teacher program with satisfactory scientific literacy and attitudes toward science?. International Journal of Science Education, 27(13), 1549-1570. https://doi. org/10.1080/09585190500186401

Clements, D. H. (2002). Computers in early childhood mathematics. Contemporary Issues in Early Childhood, 3(2), 160-181. https://doi.org/10.2304/ciec.2002.3.2.2

Concern over 'inefficient' education spending. (2015-05-12). The Nation. Retrieved from http://tinyurl.com/lrhhxnm

Connor, C. M., Morrison, F. J, \& Petrella, J. N. (2004). Effective reading comprehension instruction: Examining child $\mathrm{X}$ instruction interactions. Journal of Educational Psychology, 96(4), 682-698. https://doi.org/10.1037/0022-0663.96.4.682

Eisenhauer, J. G. (2008). Degrees of freedom. Teaching Statistics, 30(3), 75-78. doi: 10.1111/j.1467-9639.2008.00324.x

Eisenkraft, A. (2003). Expanding the 5E model. The Science Teacher, 70(6), 56-59. Retrieved from https://tinyurl.com/ybdvnvg6

Feist, G. J. (2006). The psychology of science and the origins of the scientific mind. New Haven, CT: Yale University Press.

Ford, A. Y. (2016). The Relationship between science classroom facility conditions and ninth grade students' attitude toward science (Doctoral dissertation and projects).Liberty University, Lynchburg, Va. Retrieved from http://digitalcommons.liberty. edu/doctoral/1223/

Fuller, T. (2016). The extended scientific mind. Cognitive Systems Research, 40, 75-85. https://dx.doi.org/10.1016/j. cogsys.2016.03.002

Gagne, P., \& Hancock, G. R. (2006). Measurement model quality, sample size, and solution propriety in confirmatory factor 
models. Multivariate Behavioral Research, 41(1), 65-83. https://dx.doi.org/10.1207/s15327906mbr4101_5

Gaudet, A. D., Ramer, L. M., Nakonechny, J., Cragg, J. J., \& Ramer, M. S. (2010). Small-group learning in an upper-level university biology class enhances academic performance and student attitudes toward group work. PLOS ONE, 5(12). https://doi.org/10.1371/journal.pone.0015821

Gauld, C. (1982). The scientific attitude and science education: A critical reappraisal. Science Education, 66(1), 109-121. https://doi.org/10.1002/sce.3730660113

Hair, J. F., Jr., Black, W. C., Babin, B. J., \& Anderson, R. E. (2014). Multivariate data analysis (7th ed.). Harlow: Pearson.

Hambleton, R. K., \& Rovinelli, R. J. (1986). Assessing the dimensionality of a set of test items. Applied Psychological Measurement, 10(3), 287-302. https://doi. org/10.1177/014662168601000307

Hamre, B.K., \& Pianta R.C. (2005). Can instructional and emotional support in the first-grade classroom make a difference for children at risk for school failure? Child Development, 76(5), 949-967. https://doi.org/10.1111/j.1467-8624.2005.00889.x

Heng, L. L., Surif, J., Seng, C. H., \& Ibrahim, N. H. (2015). Mastery of scientific argumentation on the concept of neutralization in chemistry: A Malaysian perspective. Malaysian Journal of Learning and Instruction, 12, 85-101. Retrieved from https:// tinyurl.com/ya8lcwmq

Hjørland, B. (2004). Domain analysis: A socio-cognitive orientation for information science research. Bulletin of the American Society for Information Science and Technology, 30(3), 1721. https://doi.org/10.1002/bult.312

Hooper, D., Coughlan, J., \& Mullen, M. R. (2008). Structural equation modeling: Guidelines for determining model fit. Electronic Journal of Business Research Methods, 6(1), 5360. Retrieved from http://tinyurl.com/zyd6od2

Houseal, A. K., Abd-El-Khalick, F., \& Destefano, L. (2014). Impact of a student-teacher-scientist partnership on students' and teachers' content knowledge, attitudes toward science, and pedagogical practices. Journal of Research in Science Teaching, 51(1), 84-115. https://doi.org/10.1002/tea.21126

Kim, T. K. (2015). T-test as a parametric statistic. Korean Journal of Anesthesiology, 68(6), 540-546. http://doi.org/10.4097/ kjae.2015.68.6.540

Kose, S., Sahin, A., Ergun, A., \& Gezer, K . (2010). The effects of cooperative learning experience on eighth-grade students' 
achievement and attitude toward science. Education, 131(1), 169-180. Retrieved from https://eric.ed.gov/?id=EJ917181

Kraisuth, D., \& Panjakajornsak, V. (2017). Thai engineer ASEAN readiness: A structural equation model analysis. Asia-Pacific Social Science Review, 16(3), 96-117. Retrieved from http://tinyurl.com/m2spsas

Lacap, M. P. (2015). The scientific attitudes of students major in science in the new teacher education curriculum. Asia Pacific Journal of Multidisciplinary Research, 3(5), 7-15. Retrieved from https://tinyurl.com/y9b4caf6

Lee, S., \& Roth, W.-M.. (2003). Science and the "Good Citizen": Community-based scientific literacy. Science, Technology, \& Human Values, 28(3), 403-424. https://doi.org/10.1177/0162 243903028003003

Leen, C. C., Hong, H., Kwan, F. N. H., \& Ying, T. W. (2016). Creative and critical thinking in Singapore schools. Nanyang Technological University. Retrieved from https://tinyurl.com/ y9hpampn

Mahoney, M. (1979). Review Paper: Psychology of the Scientist: An Evaluative Review. Social Studies of Science, 9(3), 349-375. https://doi.org/10.1177/030631277900900304

Martocchio, J. J., \& Hertenstein, E. J. (2003). Learning orientation and goal orientation context: Relationships with cognitive and affective learning outcomes. Human Resource Development Quarterly, 14(4), 413-434. https://doi.org/10.1002/hrdq.1077

Maxwell, D. O., Lambeth, D. T., \& Cox, J. T. (2015). Effects of using inquiry-based learning on science achievement for fifthgrade students. Asia-Pacific Forum on Science Learning and Teaching, 16(1). Retrieved from https://tinyurl.com/ ycwhwaza

Mecit, Ö. (2006). The effect of $7 E$ learning cycle model on the improvement of fifth-grade student's critical thinking skills. (Doctoral thesis). Middle East Technical University. Retrieved from https://tinyurl.com/yadpz4k9

Miller, J. D. (1996). Scientific literacy for effective citizenship. In R. E. Yager (Ed.), Scienceltechnology/society as reform in science education. New York, NY: State University of New York Press.

Miller, J. D., \& Prewitt, K. (1979). The measurement of the attitudes of the U.S. public toward organized science. Washington, DC: National Science Foundation. 
Moore, R. W., \& Foy, R. L. H. (1997). The scientific attitude inventory: A revision (SAI II). Journal of Research in Science Teaching, 34(4), 327-336. https://doi.org/10.1002/(sici)10982736(199704)34:4<327::aid-tea3>3.0.co;2-t

Mulaik, S. A. (2009). Linear causal modeling with structural equations. Boca Raton, Fl: Chapman \& Hall/CRC.

Nam, J., Choi, A., \& Hand, B. (2011). Implementation of the science writing heuristic (SWH) approach in 8th-grade science classrooms. International Journal of Science and Mathematics Education, 9(5), 1111-1133. https://doi.org/10.1007/s10763010-9250-3

OECD. (2016). PISA 2015 results (volume 1): Excellence and equity in education. Paris, France: OECD Publishing. Retrieved from http://dx.doi.org/10.1787/9789264266490-en

OECD. (2017). PISA 2015 results (Volume III): Students'well-being. Paris, France: OECD Publishing. Retrieved from http://dx.doi. org/10.1787/9789264273856-en

Ornstein, A. (2006). The frequency of hands-on experimentation and student attitudes toward science: A statistically significant relation (2005-51-Ornstein). Journal of Science Education and Technology, 15(3), 285-297. https://doi.org/10.1007/ s10956-006-9015-5

Osborne, J., Simon, S., \& Collins, S. (2003). Attitudes towards science: A review of the literature and its implications. International Journal of Science Education, 25(9), 1049-1079. https://doi.org/10.1080/0950069032000032199

PISA (2015). Country performance compared to the OECD average and medium-term trends. Retrieved from https://tinyurl.com/ y923c58s

Price, C. A., \& Lee, H.-S. (2013). Changes in participants' scientific attitudes and epistemological beliefs during an astronomical citizen science project. Journal of Research in Science Teaching, 50(7), 773-801. https://doi.org/10.1002/tea.21090

Putti, A. (2011). High school students' attitudes and beliefs on using the science writing heuristic in an advanced placement chemistry class. Journal of Chemical Education, 88(4), 516521. https://doi.org/10.1021/ed100135w

Rasch, D., Kubinger, K. D., \& Moder, K. (2011). The two-sample $t$-test: pre-testing its assumptions does not pay off. Statistical Papers, 52(1), 219-231. https://doi.org/10.1007/s00362-0090224-X

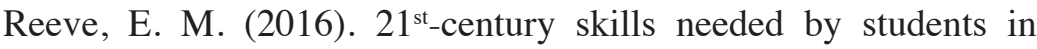
technical and vocational education and training (TVET). 
Asian International Journal of Social Sciences, 16(4), 62-74. https://doi.org/10.29139/aijss.20160404

Rujivanarom, P. (2016, December 14). School system's failure to teach logical thinking linked to low PISA scores. The Nation. Retrieved from http://tinyurl.com/168ugux

ŞAN, İsmail \& İhsan Boran, Ali. (2013). Scientific attitude levels of gifted students (a case from Malatya). Journal of Theoretical Educational Science, 6(3), 434-454.http://dx.doi.org/10.5578/ keg.5956

Shin, S., Choi, A., \& Park, J.-Y. (2013). The Effects of the Science writing heuristic approach on the middle school students' achievements. Journal of the Korean Association for Science Education, 33(5), 952-962. https://doi.org/10.14697/ jkase.2013.33.5.952

Simpson, R. D., \& Oliver, J. S. (1985). Attitude toward science and achievement motivation profiles of male and female science students in grades six through ten. Science Education, 69(4), 511-525. https://doi.org/10.1002/sce.3730690407

Smith, T. J., Pasero, S. L., \& McKenna, C. M. (2014). Gender effects on student attitude toward science. Bulletin of Science, Technology \& Society, 34(1-2), 7-12. https://doi. org/10.1177/0270467614542806

Sofiani, D., Maulida, A. S., Fadhillah, N., \& Sihite, D. Y. (2017). Gender differences in students' attitude towards Science. Journal of Physics: Conference Series, 895, 1-7. https://doi. org/10.1088/1742-6596/895/1/012168

Sothayapetch, P., Lavonen, J., \& Juuti, K. (2013). A comparative analysis of PISA scientific literacy framework in Finnish and Thai science curricula. Science Education International 24(1), 78-97. Retrieved from http://tinyurl.com/maxq9tv

Srikoon, S., Bunterm, T., Nethanomsak, T., \& Ngang, T. K. (2017). A comparative study of the effects of the neurocognitivebased model and the conventional model on learner attention, working memory and mood. Malaysian Journal of Learning and Instruction, 14(1), 83-110. Retrieved from https://files. eric.ed.gov/fulltext/EJ1150726.pdf

Süerdem, A., \& Çağliyor, S. (2016). The effects of scientific literacy on participation to political decision making. SHS Web of Conferences, 26. https://doi.org/10.1051/ shsconf $/ 20162601064$

Tabachnick, B. G., \& Fidell, L. S. (2013). Using multivariate 
statistics. New York, NY: Pearson Education.

Thailand Science Technology and Innovation Profile. (2014, February). Ministry of Science and Technology (Thailand). Retrieved from http://tinyurl.com/jspqebs

Trnova,E., \& Trna, J. (2014). Implementation of creativity in science teacher training. International Journal on New Trends in Education and their Implications, 5(3), 54-63. Retrieved from http://www.ijonte.org/FileUpload/ks63207/File/06.trnova.pdf

Turner, R. C., \& Carlson, L. (2003). Indexes of item-objective congruence for multidimensional items. International Journal of Testing, 3(2), 163-171. http://dx.doi.org/10.1207/ S15327574IJT0302_5

UNESCO Bangkok (2011). Higher education and technical and vocational education and training. Retrieved from http:// tinyurl.com/mwj8dnl

Van Aalderen-Smeets, S. I., Walma van der Molen, J. H., \& Asma, L. J. F. (2012). Primary teachers' attitudes toward science: A new theoretical framework. Science Education, 96(1), 158182. https://doi.org/10.1002/sce.20467

Van Laar, E., van Deursen, A. J. A. M., van Dijk, J. A. G. M., \& de Haan, J. (2017). The relation between 21st-century skills and digital skills: A systematic literature review. Computers in Human Behavior, 72, 577-588. https://doi.org/10.1016/j. chb.2017.03.010

Varela, F. J., Thompson, E. T., \& Rosch, E. (1993). The Embodied mind. Cognitive science and human experience. Cambridge, MA: MIT Press.

Weinburgh, M. (1995). Gender differences in student attitudes toward science: A meta-analysis of the literature from 1970 to 1991. Journal of Research in Science Teaching, 32(4), 387398. https://doi.org/10.1002/tea.3660320407

Weinburgh, M. H. (2000). Gender, ethnicity, and grade level as predictors of middle school students' attitudes toward science. Retrieved from https://eric.ed.gov/?id=ED442662

Yamtinah, S., Masykuri, M., Ashadi, \& Shidiq, A. S. (2017). Gender differences in students' attitudes toward science: An analysis of students' science process skill using testlet instrument. AIP Conference Proceedings, 1868(1). https:// doi.org/10.1063/1.4995102

Yuenyong, C. (2013). Enhancing scientific literacy in Thailand. Global Studies of Childhood, 3(1), 86-98. https://doi. org/10.2304/gsch.2013.3.1.86 